\title{
Effect of oil palm leaf treatment of crude oil impinged soil on biochemical indices of cowpea (vigna unguiculata) seedlings
}

\author{
Fidelis Ifeakachuku Achuba \\ Department of Biochemistry, Delta State University, PMB 1, Abraka, Nigeria. \\ [Received: September 25, 2019 Accepted: November 04, 2019]
}

\section{Abstract}

The possibility of oil palm leaf (OPL) being applied as ameliorative agent in unrefined petroleum oil tainted soil was examined in this study. Six treatment protocols, comprising group 1 (untainted soil), group 2 (untainted soil $+50 \mathrm{~g}$ of OPL), group 3 (untainted soil $+100 \mathrm{~g}$ of OPL), group 4 (petroleum oil tainted soil), group 5 (petroleum oil tainted soil $+50 \mathrm{~g}$ of OPL) and group 6 (petroleum tainted soil $+100 \mathrm{~g}$ of OPL) were used in this study. A decrease in photosynthetic pigments of cowpea seedlings in unrefined oil tainted soil compared to the cowpea seedlings in control was noted. Cowpea seedlings raised in unrefined oil tainted soil had lower levels of antioxidants relative to the control. Conversely, lipid peroxidation was elevated in seedlings raised in unrefined oil tainted soil. The activities of glutathione $s$ - transferase, sulphite oxidase, xanthine oxidase and aldehyde oxidase significantly reduced in cowpea seedlings raised in soil tainted with unrefined oil without addition of OPL as compared to those of the control and all OPL protocols. The significant improvement in photosynthetic pigments, beta carotene as well as the antioxidant profile of cowpea seedlings in untainted soil treated with OPL when compared with those in control group, alongside the substantial ameliorative effect on chlorophyll, beta carotene and the antioxidant profile of cowpea seedlings in OPL amended soil, suggests that OPL addition to unrefined petroleum oil tainted soil reduced petroleum toxicity on cowpea seedlings.

Keywords: Enzymes, oil palm, petroleum, seedlings, soil, remediation

\section{Introduction}

Crude oil is a fossil fuel occurring underground and is composed of many thousands of organic compounds amongst which hydrocarbons predominate (Alkindi et al., 1996). Adulteration of soil by petroleum derivatives is a widespread ecological problem (Sivaraj et al., 2014). The soils of the Niger Delta region of Nigeria are heavily tainted with unrefined oil and its refined products because this region hosts oil related operations and industries (Nwaogu and Onyeze, 2014; Anochie and Mgbemena, 2015). The dominant route of pollution of soils include oil well drilling and production operations, oil spillage and haphazard dumping of petroleum-related substances into the environment by auto mobile mechanics (Anoliefo et al., 2001; Onwurah et al., 2007; Osuagwu et al., 2017). Petroleum in its various forms has a negative impact on all shades of animal and plant species (Achuba, 2008; Nwaogu and Onyeze, 2010). The pollution of the soil by crude oil and related chemicals undesirably disturbs both physical and chemical properties of the soil. It can lead to water and oxygen shortages, deficiency in nitrogen and phosphorous, reduced soil microorganisms and fertility (Samina and Adams, 2002; Achuba and Peretiemo-Clarke, 2008). Besides harming the environment, toxic chemicals in crude oil can pose serious threats to many living organisms (Adedoku and Ataga, 2007; Achuba and Okoh, 2015, Achuba, 2018a).

Crude oil affects plants in a variety of ways such as alterations in the anatomical, physiological and metabolic processes (Daniel-Kalio and Pepple, 2006; Adenipekun et al., 2008; Achuba, 2006; Achuba, 2010). Plants raised in soils tainted with petroleum have been reported to exhibit retardation in growth parameters (Onwusiri et al., 2017; Osuagwu et al., 2017) and metabolic alterations (Achuba, 2006). Moreover, plants raised in crude oil tainted soil were reported to exhibit increased free radical generation, oxidative stress and lipid peroxidation (Achuba, 2014). Recently, spent engine oil was reported to adversely affect the germination and growth parameters of fruited pumpkin (T. occidentalis), Zea mays, Arachis hypogea and Vigna unguiculata (Onwusiri et al., 2017; Osuagwu et al., 2017)

Tropical African palm tree, Elaeis guineensis Jacq., is a highly profitable cash crop and is reputed economically, the most efficient oil crop worldwide (Dislich et al., 2017). Oil palm fond (OPF) is the largest oil palm biomass generated and is a promising source of raw materials (Ooi et al., 2017). Recently, the improvement in soil enzyme activities upon treatment of polluted soil with oil palm leaf was

\footnotetext{
*Email: achubbcha@yahoo.com
} 
reported (Achuba, 2018b). However, no study has been carried out to ascertain whether oil palm leaf can remediate the adversative upshot of crude oil tainted soil on plants. This study therefore aimed at evaluating the preventive capacity of oil palm leaf on the anomalies in the metabolism of cowpea seedlings raised in crude oil tainted soil.

\section{Materials and Methods}

The soil sample and oil palm leaves used were previously described (Achuba, 2018b). Similarly, cowpea seeds were obtained as earlier reported (Achuba and Okoh, 2015). Analytical grade reagents were used for determination of each parameter:

\begin{tabular}{lc} 
Parameters & Values \\
$\mathrm{pH}$ & $7.01 \pm 0.02$ \\
Organic matter (\%) & $0.47 \pm 0.12$ \\
Total Nitrogen (\%) & $0.16 \pm 0.01$ \\
Phosphorus (ppm) & $3.31 \pm 0.32$ \\
Cation exchange capacity $(\mathrm{Meq} / 100 \mathrm{~g})$ & $6.64 \pm 0.70$ \\
\hline \multicolumn{2}{c}{ Source: Achuba $(2018 \mathrm{~b})$}
\end{tabular}

\section{Experimental design}

Six treatment protocols, comprising group 1( seedlings cultivated in $400 \mathrm{~g}$ of untainted soil), group 2(seedlings cultivated in $400 \mathrm{~g}$ of untainted soil $+50 \mathrm{~g}$ of OPL), group 3 ( seedlings cultivated in $400 \mathrm{~g}$ of untainted soil $+100 \mathrm{~g}$ of OPL), group 4 ( seedlings cultivated in $400 \mathrm{~g}$ of unrefined oil impacted soil), group 5 ( seedlings cultivated in $400 \mathrm{~g}$ of unrefined oil tainted soil $+50 \mathrm{~g}$ of OPL) and group 6 ( seedlings cultivated in $400 \mathrm{~g}$ of unrefined oil tainted soil $+100 \mathrm{~g}$ of OPL) were used in this study. Planting of viable seeds was done as described earlier (Achuba, 2006).

\section{Determination of chlorophyll and carotene}

Chlorophyll and carotene were determined as briefly described. The leaf $(1.0 \mathrm{~g})$ was weighed, homogenized and extracted with $80 \%$ acetone. This was followed by filtration and centrifugation at $2500 \mathrm{rpm}$ for ten minutes. The absorbance of the supernant was read at $480,510,645$ and $663 \mathrm{~nm}$. The amount of chl. a, chl.b and carotenoid were calculated using the formula of Duxbury and Yentsch (1956).

\section{Preparation of homogenate biochemical assays}

Homogenate for biochemical analysis was prepared thus. The leaf was removed from the stalk washed with icecold water $\left(4^{0} \mathrm{C}\right), 0.5 \mathrm{~g}$ measured, added to $0.1 \mathrm{~g}$ butylated hydroxy toluene $(\mathrm{BTH})$ and homogenized with $10 \mathrm{~mL}$ of 0.05M Phosphate buffer, $\mathrm{pH} 7.4$ with a blender immersed kept inside ice. The mixture was filtered with cheese cloth and the filtrate was centrifuged at $7000 \mathrm{~g}$ for 20 minutes $\left(4^{0} \mathrm{C}\right)$ to generate the supernatant $(\mathrm{S} 1)$ used for the determination of various biochemical indices

\section{Determination of lipid peroxidation and non- enzymatic antioxidants}

Lipid peroxidation was determined with the method of Gutteridge and Wilkins (1982). This method is used to evaluate Malondialdehyde (MDA), an index of lipid peroxidation with a molar extinction coefficient of $1.56 \times 10^{5}$ $\mathrm{M} / \mathrm{cm}$. The supernant (S1) prepared earlier was used to assay for reduced glutathione (EIIman, 1959) which is based on the development of chromophore that absorbs light maximally at $412 \mathrm{~nm}$. A measured amount of the leaf, $2.0 \mathrm{~g}$, was added to $20 \mathrm{~mL}$ of $0.05 \mathrm{M}$ phosphate buffer, $\mathrm{pH} 7.4$ and acidified with $5 \%$ metaphosphoric acid (in a ratio of sample to acid 5: $1 \mathrm{v} / \mathrm{v}$ ). Ascorbic acid was determined by titration using 2,6-dichlorophenol-indophenol (DCIP) as electron acceptor. (Achuba 2008). Uric acid in the plant extract was determined using commercial kits supplied by Teco Diagnostics, USA following the procedure in the user's manual (Caraway and Hard, 1963).

\section{Determination of enzymatic antioxidants}

Superoxide dismutase (SOD) activity was determined based on its ability to inhibit the oxidation of epinephrine by superoxide anion. One unit of superoxide dismutase activity is calculated as the amount of enzyme required for $50 \%$ inhibition of the oxidation of epinephrine to adrenochrome at $480 \mathrm{~nm}$ per min (Misra and Fridovich 1972). Manganese dependent SOD was assayed in the presence of $1 \mathrm{mM}$ $\mathrm{NaCN}$ to inhibit $\mathrm{Cu}-\mathrm{ZnSOD}$ activity, and the cytosolic $\mathrm{Cu}-$ ZnSOD activity was determined as the difference between total and cyanide -sensitive enzyme activity (Crapo et al., 1978). The method of Cohen et al. (1970) was used to determine catalase activity. This reaction is based on monitoring the disappearance of the purple colour of potassium permanganate at $480 \mathrm{~nm}$ at $30-60$ intervals, was due to oxygen generated by the breakdown of hydrogen peroxide by catalase. Glutathione peroxidase was measured as described by Rani et al. (2004). This is based on the reduction of hydrogen peroxide and organic peroxides to the corresponding stable alcohols and water using cellular glutathione as the reducing reagent producing a chromophore that absorbs maximally at $412 \mathrm{~nm}$.

\section{Determination of xenobiotic metabolizing enzymes}

The activity of glutathione-s-transferase (GST) was determined with the method of Habig et al. (1974) based on 
the reaction between 1-chloro-2, 4, dinitrobenzene (CDNB) and reduced glutathione to produce a dinitrophenyl thioether which absorbs maximally at $340 \mathrm{~nm}$. The activity of xanthine oxidase was assayed by the method of Stirpe and Della Corte (1969) with xanthine as the substrate and oxygen as electron acceptor. The enzyme activity is expressed in units per gram tissue. Aldehyde oxidase (AO) was assayed following the method prescribed by Omarov et al. (1998) which is dependent on the conversion of benzaldehyde to benzoate using 2,6-dichlorophenol (DCIP) as the electron by the enzyme. Sulphite oxidase (SO) was assayed following the method prescribed by Macleod et al. (1961) which is dependent on the conversion of sulphite to sulphate using 2,6-dichlorophenol (DCIP) as the electron by the enzyme

\section{Statistical analysis of data}

Analysis of variance (ANOVA) was used to analyze the data for statistical difference and significance was set at $p$ values $<0.05$. seedlings, meanwhile, addition of $100 \mathrm{~g}$ of OPL to crude oil tainted soil significantly increased the photosynthetic pigments and beta carotene contents of cowpea seedlings.

Treatment of untainted soil with $50 \mathrm{~g}$ OPL caused a substantial increase in lipid peroxidation while addition of $100 \mathrm{~g}$ OPL decreased in lipid peroxidation parallel to the control (group 1) (Table 2). Tainting soil with crude oil caused substantial elevation of lipid peroxidation as compared to the control group. However, addition of oil palm leaf to crude oil tainted soil caused a substantial $(p<0.05)$ decrease in lipid peroxidation whereas glutathione and vitamin $\mathrm{C}$ of cowpea seedlings were increased by treatment of untainted soil with OPL when compared to untreated soil (group 1). Cowpea seedlings cultivated in crude oil tainted soil had a substantial decrease in the levels of glutathione and vitamin $\mathrm{C}$ related to the control but the addition of oil palm leaf to the crude oil tainted soil meaningfully increased the levels of glutathione and vitamin $\mathrm{C}$ in cowpea seedlings as paralleled to those cultivated in crude oil tainted soil without OPL. Cowpea seedlings raised

Table 1: Oil palm leaf alters photosynthetic pigments in cowpea seedlings cultivated in crude oil tainted soil

\begin{tabular}{lcrcc}
\hline GROUPS & Total chlorophyll $(\mathbf{m g} / \mathbf{g})$ & Chlorophyll b $\mathbf{~ m g / g )}$ & Chlorophyll b (mg/g) & Beta Carotene (mg/g) \\
\hline 1 & $209.5 \pm 1.2^{\mathrm{a}}$ & $124.0 \pm 1.4^{\mathrm{a}}$ & $80.75 \pm 1.7^{\mathrm{a}}$ & $22.27 \pm 1.1^{\mathrm{a}}$ \\
2 & $210.0 \pm 6.0^{\mathrm{a}}$ & $129.0 \pm 2.5^{\mathrm{a}}$ & $67.0 \pm 2.1^{\mathrm{c}}$ & $25.2 \pm 1.0^{\mathrm{b}}$ \\
3 & $213.25 \pm 2.2^{\mathrm{a}}$ & $120.25 \pm 2.6^{\mathrm{b}}$ & $82.25 \pm 1.7^{\mathrm{b}}$ & $26.20 \pm 1.0^{\mathrm{b}}$ \\
4 & $153.25 \pm 7.5^{\mathrm{b}}$ & $98.0 \pm 2.1^{\mathrm{d}}$ & $57.25 \pm 2.9^{\mathrm{d}}$ & $19.52 \pm 1.1^{\mathrm{c}}$ \\
5 & $182.25 \pm 8.1^{\mathrm{ab}}$ & $109.0 \pm 2.6^{\mathrm{c}}$ & $71.25 \pm 2.2^{\mathrm{c}}$ & $22.95 \pm 1.3^{\mathrm{a}}$ \\
6 & $204.75 \pm 2.2^{\mathrm{a}}$ & $119.5 \pm 1.2^{\mathrm{b}}$ & $78.0 \pm 1.6^{\mathrm{a}}$ & $22.6 \pm 1.8^{\mathrm{a}}$ \\
\hline
\end{tabular}

Results are expressed as mean + SEM. Results with different letters in column are significantly different.

Table 2: oil palm leaf alters lipid peroxidation and non-enzymatic antioxidants in cowpea seedlings cultivated in crude oil tainted soil

\begin{tabular}{|c|c|c|c|c|}
\hline GROUPS & $\begin{array}{c}\text { Lipid peroxidation } \\
\left(\mathrm{nMol} \mathrm{cm}^{-3}\right)\end{array}$ & $\begin{array}{c}\text { Reduced glutathione } \\
\left(\mathrm{ug} \mathrm{g}^{-1}\right)\end{array}$ & $\begin{array}{c}\text { Vitamin C } \\
\left(\text { ug g g }^{-1}\right)\end{array}$ & $\begin{array}{c}\text { Uric Acid } \\
\left(\text { ug g g }^{-1}\right)\end{array}$ \\
\hline 1 & $1.09 \pm 0.01^{\mathrm{b}}$ & $0.40 \pm 0.09^{\mathrm{e}}$ & $3.64 \pm 0.15^{\mathrm{d}}$ & $3.52 \pm 0.09^{\mathrm{c}}$ \\
\hline 2 & $1.19 \pm 0.14^{c}$ & $0.48 \pm 0.09^{\mathrm{d}}$ & $3.67 \pm 0.59^{d}$ & $3.00 \pm 0.18^{c}$ \\
\hline 3 & $1.05 \pm 0.01^{\mathrm{a}}$ & $0.49 \pm 0.13^{\mathrm{d}}$ & $4.22 \pm 0.38^{\mathrm{e}}$ & $3.06 \pm 0.26^{\mathrm{c}}$ \\
\hline 4 & $1.39 \pm 0.18^{f}$ & $0.25 \pm 0.01^{\mathrm{a}}$ & $2.37 \pm 0.52^{\mathrm{a}}$ & $1.84 \pm 0.08^{\mathrm{a}}$ \\
\hline 5 & $1.34 \pm 0.10^{\mathrm{e}}$ & $0.27 \pm 0.03^{b}$ & $3.04 \pm 0.48^{b}$ & $2.38 \pm 0.07^{\mathrm{b}}$ \\
\hline 6 & $1.21 \pm 0.08^{\mathrm{d}}$ & $0.29 \pm 0.02^{\mathrm{c}}$ & $3.37 \pm 0.09^{\mathrm{c}}$ & $3.01 \pm 0.43^{\mathrm{c}}$ \\
\hline
\end{tabular}

Results are expressed as mean + SEM. Results with different letters in column are significantly different.

\section{Results}

The results in Table 1 show that treatment of untainted soil with oil palm leaf (OPL) improved the photosynthetic pigments and beta carotene content of cowpea seedlings compared to the control (group 1). On the contrary, adulteration of soil with crude oil significantly $(p<0.05)$ decreased the photosynthetic pigments and beta carotene level (group 4). However, addition of $50 \mathrm{~g}$ of OPL to crude oil tainted soil did not significantly increase the photosynthetic pigments and beta carotene level of cowpea in untainted soil treated with OPL exhibited decrease in uric acid content comparative to the control. Cowpea seedlings cultivated in crude oil tainted soil had a substantial decrease in uric acid levels as paralleled to the control. Nevertheless, cowpea seedlings cultivated in soil tainted with crude oil and modified with OPL had a substantial increase in uric acid as paralleled to those cultivated in crude oil adulterated soil.

In Table 3, treatment of untainted soil with OPL significantly increased the levels of antioxidant enzymes in 
cowpea seedlings paralleled to the control. Conversely, adulteration of soil with crude oil decreased the activities of the enzymes relative to the control (group 1). But addition of OPL to the crude oil tainted soil instigated a substantial $(p<0.05)$ increase in the activities of these enzymes while no difference was observed in the activities of $\mathrm{Cu} / \mathrm{ZnSOD}$ in all the groups. Treatment of untainted soil with OPL meaningfully reduced the level of MnSOD as paralleled to processes in plants (Achuba, 2006; Achuba and Asagba 2015). The observed marked decrease in the levels of photosynthetic pigments and beta carotene in cowpea seedlings raised in crude oil tainted soil (Table 1) correlates with previous studies which found carotenoids and photosynthetic products decreased by crude oil. (Achuba, 2006; Agbogidi and Ilondu, 2013). Onwusiri et al. (2017) also reported marked reduction in growth parameters in

Table 3: Oil palm leaf alters enzymatic antioxidants of cowpea seedlings cultivated in crude oil tainted soil

\begin{tabular}{|c|c|c|c|c|c|}
\hline Groups & $\begin{array}{l}\text { Total SOD } \\
\left(\text { Unit }^{-1} \mathbf{f w}\right)\end{array}$ & $\begin{array}{l}\text { Cu/ZnSOD } \\
\left(\text { Unit g }^{-1} \text { fw) }\right.\end{array}$ & $\begin{array}{c}\text { MnSOD } \\
\left(\text { Unit g }^{-1} \text { fw) }\right.\end{array}$ & 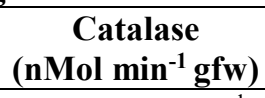 & $\begin{array}{c}\text { Glutathione peroxidase } \\
\left(\mathrm{nMol} \mathrm{min}^{-1} \mathbf{g f w}\right)\end{array}$ \\
\hline 1 & $2.31 \pm 0.12^{\mathrm{c}}$ & $1.78 \pm 0.04^{\mathrm{a}}$ & $0.93 \pm 0.04^{\mathrm{e}}$ & $1.23 \pm 0.09^{\mathrm{d}}$ & $6.91 \pm 0.14^{\mathrm{b}}$ \\
\hline 2 & $2.33 \pm 0.06^{\mathrm{e}}$ & $1.82 \pm 0.04^{\mathrm{a}}$ & $0.92 \pm 0.05^{\mathrm{d}}$ & $1.24 \pm 0.08^{\mathrm{d}}$ & $7.98 \pm 0.03^{c}$ \\
\hline 3 & $2.39 \pm 0.09^{f}$ & $1.84 \pm 0.03^{\mathrm{a}}$ & $0.91 \pm 0.02^{\mathrm{c}}$ & $1.34 \pm 0.05^{\mathrm{e}}$ & $8.50 \pm 0.16^{\mathrm{c}}$ \\
\hline 4 & $1.96 \pm 0.04^{\mathrm{a}}$ & $1.61 \pm 0.16^{\mathrm{a}}$ & $0.64 \pm 0.09^{\mathrm{a}}$ & $1.03 \pm 0.05^{\mathrm{a}}$ & $5.23 \pm 0.02^{\mathrm{a}}$ \\
\hline 5 & $2.32 \pm 0.10^{\mathrm{d}}$ & $1.67 \pm 0.09^{\mathrm{a}}$ & $0.75 \pm 0.08^{b}$ & $1.12 \pm 0.06^{\mathrm{b}}$ & $5.88 \pm 0.08^{\mathrm{ab}}$ \\
\hline 6 & $2.26 \pm 0.03^{\mathrm{b}}$ & $1.84 \pm 0.05^{\mathrm{a}}$ & $0.93 \pm 0.04^{\mathrm{e}}$ & $1.18 \pm 0.03^{c}$ & $6.08 \pm 0.04^{b}$ \\
\hline
\end{tabular}

Results are expressed as mean + SEM. Results with different letters in column are significantly different.

Table 4: Oil palm leaf alters drug metabolizing enzymes in cowpea seedlings cultivated in crude oil tainted soil

\begin{tabular}{llcll}
\hline Groups & $\begin{array}{l}\text { Glutathione-s- transferase } \\
\left(\mathbf{U n i t} \mathbf{~ g}^{-1} \mathbf{f w}\right)\end{array}$ & $\begin{array}{c}\text { Xanthine oxidase } \\
\left(\mathbf{U n i t} \mathbf{~ g}^{-1} \mathbf{f w}\right)\end{array}$ & $\begin{array}{l}\text { Aldehyde oxidase } \\
\left(\mathbf{U n i t} \mathbf{~ g}^{-1} \mathbf{f w}\right)\end{array}$ & $\begin{array}{l}\text { Sulphite oxidase (Unit } \\
\left.\mathbf{g}^{-1} \mathbf{f w}\right)\end{array}$ \\
\hline 1 & $1.77 \pm 0.07^{\mathrm{d}}$ & $3.18 \pm 0.41^{\mathrm{d}}$ & $1.58 \pm 0.06^{\mathrm{c}}$ & $2.40 \pm 0.08^{\mathrm{b}}$ \\
2 & $2.05 \pm 0.10^{\mathrm{e}}$ & $3.20 \pm 0.38^{\mathrm{d}}$ & $1.58 \pm 0.07^{\mathrm{c}}$ & $3.52 \pm 0.18^{\mathrm{d}}$ \\
3 & $2.18 \pm 0.10^{\mathrm{f}}$ & $3.93 \pm 0.22^{\mathrm{e}}$ & $1.73 \pm 0.12^{\mathrm{d}}$ & $3.54 \pm 0.20^{\mathrm{d}}$ \\
4 & $1.46 \pm 0.09^{\mathrm{a}}$ & $1.94 \pm 0.17^{\mathrm{a}}$ & $1.07 \pm 0.10^{\mathrm{a}}$ & $1.95 \pm 0.14^{\mathrm{a}}$ \\
5 & $1.60 \pm 0.02^{\mathrm{b}}$ & $2.13 \pm 0.15^{\mathrm{c}}$ & $1.36 \pm 0.09^{\mathrm{b}}$ & $2.53 \pm 0.43^{\mathrm{c}}$ \\
6 & $1.64 \pm 0.04^{\mathrm{c}}$ & $2.86 \pm 0.16^{\mathrm{c}}$ & $1.38 \pm 0.06^{\mathrm{b}}$ & $2.66 \pm 0.12^{\mathrm{c}}$ \\
\hline
\end{tabular}

Results are expressed as mean + SEM. Results with different in column letters are significantly different.

the control group while addition of OPL to the unrefined petroleum tainted soil occasioned in substantial elevation of MnSOD of cowpea seedlings.

Table 4 depicts a significant $(<0.05)$ increase in the levels of glutathione s-transferase and the oxidases in cowpea seedlings raised in untainted soil treated with $100 \mathrm{~g}$ OPL compared to the control. The addition of 50g OPL to the soil did not cause significant increase in xanthine oxidase and aldehyde oxidase. The levels of these enzymes significantly reduced in cowpea seedlings cultivated in soil tainted with crude oil without addition of OPL. However, adding OPL to soil tainted with crude oil caused a substantial increase in the levels of these enzymes compared with the group raised in soil tainted with crude oil without adding OPL.

\section{Discussion}

Several studies have established petroleum-derived substances as phytotoxic (Achuba, 2010; Bona et al., 2011; Al-Hawas et al., 2012). These substances are known to negatively influence both physiological and biochemical fluted pumpkin raised in soil adulterated with used petroleum oil. The decreased levels of photosynthetic pigments and beta carotene may be centered on crude oilstimulated alteration of soil chemistry (Achuba and Peretiemo-Clarke, 2008). Crude oil in the soil had been implicated to disrupt $\mathrm{C}-\mathrm{N}$ balance, limits soil nitrogen and phosphorus, and causes insufficient aeration and physiological drought (Nwaogu et al., 2008; Das and Chandran, 2011), which accounts for the reduction in the amount of photosynthetic pigments and beta carotene. Moreover, Agbogidi and Ilondu (2013) reported that spent engine oil caused reduction in the stomata indices of the leaf with eventual decrease in the photosynthetic products. Notwithstanding, the photosynthetic pigments and beta carotene content of cowpea seedlings improved by adding oil palm leaf (OPL) to the crude oil tainted soil which became significant at $100 \mathrm{~g}$ of OPL while cowpea seedlings raised in untainted soil treated with OPL had higher contents of photosynthetic pigments and beta carotene. The positive effects of OPL on the cowpea seedlings may be attributed to its ability to enrich the soil with nutrients and its richness in 
antioxidants (Ng and Choo, 2010; Comte et al., 2012). The observed significantly $(p<0.05)$ higher levels of photosynthetic pigments and beta carotene of cowpea seedlings raised in untainted soils treated with OPL especially at $100 \mathrm{~g}$ of OPL compared to those raised in untainted soil (controls) suggests that OPL can be used as an organic fertilizer. Improvement in crop performance on application of organic materials to the soil had been reported (Arif et al.,2018; Billah et al.,2018; Ali et al.,2018; Achuba and Oshiokpu,2019). This gives credence to the assertion that OPL can be a potential organic nutrient. Moreover, the levels of photosynthetic pigments and beta carotene of cowpea seedlings raised in crude oil tainted soils improved upon addition of OPL compared to seedlings raised in crude oil tainted soil without treatment, thus suggests that OPL can be potentially used to remediate crude oil tainted soil.

Crops raised in soils tainted with crude oil and its byproducts have been associated with increased oxidative stress, as evidenced by increased lipid peroxidation and reduction in antioxidant enzymes (Ortega-Villasante, 2005; Achuba, 2010; Dietz, 2010; Al-Hawas et al., 2012). This agrees with the present investigation that reported elevated lipid peroxidation and decreased glutathione and vitamin $\mathrm{C}$ and uric acid, though these indices were reversed by OPL addition to crude oil tainted soil (Table 2). Attenuation of crude oil toxicity in cowpea seedlings by organic substances is in literature (Achuba and Erhijivwo, 2017; Achuba and Iserhienrhien, 2018).

Antioxidant enzymes constitute mutually supportive team of defense against damaging effects of oxyradicals in plants (Asada, 1994; Achuba 2010). While reports on the effects of contaminants on physiological processes of plants have always been an increase in SOD, the present result showed that addition of crude oil to soil caused reduction of various SOD activities (Table 3). This agrees with the information in literature (Achuba, 2014). Achuba (2014) observed an increased SOD in cowpea seedlings at higher doses of petroleum and a decreased level of SOD at lower doses. According to Sgherri et al (2000), different levels of SOD activity might occur depending on stress intensity, species of plant and growth conditions. Moreover, organic materials- stimulated increase in yield and SOD activity in plants have recently been observed (AlAbdallah et al., 2017; El-Batanony, 2017). The decreased total SOD suggests increase in superoxide ion production and insufficient adaptive mechanism.

The addition of oil palm leaf to the crude oil tainted soil improved the activities of xenobiotic metabolizing enzymes (Table 4). These enzymes have been reported to play a vital role in the inactivation of xenobiotics in animals (Asagba et al., 2017). Thus, suggesting that oil palm leaf in soil may either reduce the absorption of crude oil from the soil or stimulate microbial biodegradation of crude oil. This observation is akin to former study where addition of saw dust improved the performance of Abelmoschus esculentus $L$ (Tanee et al., 2017). This may be the basis for the enhancement of the drug metabolizing enzymes in cowpea seedlings on adding OPL to the soil polluted with crude oil. This indicates that adding OPL to crude oil tainted soil improved the ability of cowpea seedlings to deal with noxiousness of crude oil when present in soil.

\section{Conclusion}

This study shows that treatment of untainted soil with OPL significantly improved photosynthetic parameters as well as the antioxidant profile of cowpea seedlings when compared with those in control group. This suggests that OPL can be used as soil conditioner. The study also shows that adulteration of soil with crude oil has adverse effects on the photosynthetic pigments, enzymatic and non-enzymatic antioxidant systems as well as detoxifying capacity of cowpea seedlings. However, amendment of crude oil tainted soil with OPL produced substantial ameliorative effects on the photosynthetic pigments, antioxidant profile and detoxifying capacity of cowpea seedlings, which indicates the reconditioning potential of OPL on crude oil tainted soil.

\section{Acknowledgements}

The author appreciates the technical support of $\mathrm{Mr}$. Murphy D. Ogwumu and staff of Biochemistry laboratory of Delta State University, Abraka.

\section{References}

Achuba, F.I. 2014. Petroleum products in soil mediated oxidative stress in cowpea (Vigna unguiculata) and maize (Zea mays) seedlings. Open Journal Soil Science 4: 417-435. doi: 10.4236/ojss.2014.412042.

Achuba F.I. and P.N. Okoh. 2015. Effects of petroleum products in soil on $\alpha$-amylase, starch phosphorylase and peroxidase activities in cowpea and maize seedlings. American Journal Experimental Agriculture 6(2): 112120.

Achuba, F.I. and S.O. Asagba. 2015.Glutathione-stransferase activity in cowpea (Vigna unguiculata) and maize (Zea mays) seedlings exposed to petroleum products in soil. Biokemistri 27 (2): 117-122

Achuba, F.I. and L.O. Iserhienrhien. 2018. Effects of soil treatment with abattoir effluent on morphological and biochemical profiles of cowpea seedlings ( $V$. unguiculata) grown in gasoline polluted soil. Ife Journal Science 19 (3): 051 - 059

Achuba, F.I. 2006. The effects of sublethal concentrations of crude oil on the growth and metabolism of cowpea 
(Vigna unguiculata) seedlings. The Environmentalist 26 (1):17- 20 .

Achuba, F.I. 2008. African land snail Achatina marginatus, as bioindicator of environmental pollution. NorthWestern Journal of Zoology 4 (1): 1-5.

Achuba, F.I. 2018a. Modulation of crude oil induced alteration of oxidative stress indices in rat by red palm oil. Journal of Applied Science and Environmental Management. 22 (6): 929-932

Achuba, F.I. 2018b. Oil palm leaf treatment alters soil enzyme activities of crude oil polluted soil. FUW Trends in Science and Technology Journal 3 (1): 167170.

Achuba, F.I. and P.O. Erhijivwo. 2017. The effect of abattoir waste water on the metabolism of cowpea seedlings grown in diesel contaminated soil. Nigerian Journal of Science and Environment 15 (1): 155-162.

Achuba, F.I. 2010. Spent engine oil mediated oxidative stress in cowpea (Vigna unguiculata) seedlings. Electronic Journal of Environment, Agriculture and Food Chemistry 9(5): 910-917.

Achuba, F.I. and M.N. Oshiokpu. 2019. Growth and metabolic activities of cowpea seedlings exposed to artificial pond wastewater-treated soil. International Journal of Recycling of Organic Waste in Agriculture 8: 351-359. doi.org/10.1007/s40093-019-0262-x.

Achuba, F.I. and B.O. Peretiemo-Clarke. 2008. Effect of spent engine oil on soil catalase and dehydrogenase activities. International Agrophysics 22 (1): 1- 4.

Adedokun, O.M. and A.E. Ataga. 2007. Effects of amendments and bioaugumentation of soil polluted with crude oil, automotive gasoline oil, and spent engine oil on the growth of cowpea (Vigna unguiculata L. Walp). Science Research Essay 2: 147-149.

Adenipekun, C.O., O.J. Oyetunji and L.S. Kassim. 2008. Effect of spent engine oil on the growth parameters and chlorophyll content of Corchorusolitorius Linn. Environmentalist 28: 446-450.

Agbogidi, O.M and E.M. llondu. 2013. Effects of spent engine oil on the germination and seedling growth of Moringa oleifera (Lam.). Scholar Journal of Agricultural Science 3(6): 239-243

AlAbdallah, N.M, M.O. Basalah, and S.S. Roushdy. 2017. The promotive effect of algal biofertilizers on growth and some metabolic activities of Vigna unguiculata L. under salt stress conditions Egyptian Journal of Experimental Biology (Botany) 13(2): 187-195. doi: 10.5455/egyjebb.20170616083640

Al-Hawas, G.H.S., W.M. Shukry, M.M. Azzoz and R.M.S. Al-Moaik. 2012. The effect of sublethal concentrations of crude oil on the metabolism of Jojoba (Simmodsia chinensis) seedlings. International Journal of Plant Science 3(4): 54-62.

Ali, M., Khan, Subhanullah, W. Ahmad, M. Ishaq and M. Saeed. 2018. Enhancing wheat productivity and soil physical properties of water eroded agricultural land through integrated nutrient management. Soil and Environment 37(1): 21-27. DOI:10.25252/SE/18/61450

Alkindi, A.Y.A, J.A. Brown, C.P. Waring and J.E. Collins. 1996. Endocrine, osmoregulatory, respiratory and haematological parameters in flounder exposed to the water-soluble fraction of crude oil. Journal of Fish Biology 49:1291-1305.

Anochie, U. C. and Mgbemena, O.O. 2015. Evaluation of some oil companies in the niger delta Region of Nigeria: An environmental impact Approach. International Journal of Environment and Pollution Research 3(2):13-31

Anoliefo, G.O., O.S. Isikhuen and S.O. Agbuna. 2001. Small-scale industrial village in Binin City, Nigeria: Establishment, failure and phytoxicity assessment of soils from the abandoned site. Water, Air Soil Pollution 131:169-183.

Arif, M., W. Ahmed, Tanveer-Ul-Haq, U. Jamshaid, M. Imran and S. Ahmad. 2018. Effect of rock phosphatebased compost and biofertilizer on uptake of nutrients, nutrient use efficiency and yield of cotton. Soil and Environment 37(2): 129-135.

Asada, K. 1994. Production and action of active oxygen species in photosynthetic tissues. pp.77-104. In: Causes of Photooxidative Stress and Amelioration of Defense Systems in Plants, C.H Foyer and P.M. Mullineaux, (eds.). CRC Press, Boca Raton.

Asagba, S. O., T. Ezedom and H. Kadiri. 2017. Influence of farmyard manure on some morphological and biochemical parameters of cowpea (Vigna unguiculata) seedling grown in cadmium-treated soil. Environmental Science and Pollution Research International 24(30): 23735-23743.

Billah, N.M.M, W. Ahmad, M. Ali and F. Khan. 2018. Effect of biochar particle size and biofertilizers on lentil (Lense culinarous M.) yield and available fractions of soil nutrients. Soil and Environment 37(2): 143-151.

Bona, C, M. deRezende, D. Santos and L.A. de Souza. 2011. Effect of soil contaminated by diesel oil on the germination of seeds and the growth of Schinus terebinthifolius Raddi (Anacardiaceae) Seedlings. Brazilian Archieve of Biology and Technology 54 (6): 63-69.

Caraway, W. T and Hald, P.M.1963. Uric acid. Standard Methods of Clinical Chemistry 4: 239-247. https://doi.org/10.1016/B978-1-4831-9685-5.50029-7 
Cohen, G., D. Dembiec, and J. Marcus, 1970. Measurement of catalase activity in tissue extract. Annals of Biochemistry 34: 30-38.

Comte, I., F Colin, J.K., Whalen, O. Gruenberger, and J. P. Caliman 2012. Agricultural practices in oil palm plantations and their impact on hydrological changes, nutrient fluxes and water quality in Indonesia: a review. Advances in Agronomy 116: 71-124.

Crapo, J.D., J.M. McCord, I. Fridovich, 1978. Preparation and assay of superoxide dismutases. Methods in Enzymology 53: 382-393.

Daniel-Kalio, L.A. and S.F. Pepple 2006. Effect of Bonny light crude oil pollution of soil on the growth of day flower (Commelina benghalensis L.) in the Niger Delta. Nigeria. Journal of Applied Science and Environmental Management 10: 111-114.

Das, N. and P. Chandran 2011. Microbial degradation of petroleum hydrocarbon contaminants: An Overview. Biotechnology Research International. Volume 2011: Article ID 941810, 13 pages.

Dietz, K.J. 2010. Redox-dependent regulation, redox control and oxidative damage in plant cells subjected to abiotic stress. Pp.57-70. In: Plant Stress Tolerance: Methods and Protocols, R. Sunkar (ed.). Humana Press, London,

Dislich, C., A.C. Keye, J. Salecke, Y. Kise, K.M. Meyer, M. Auliya, A.D. Barnes, M.D. Corre, K. Darras, H. Faust, B. Hess, S. Klasen, A. Knoh, H. Kreft, A. Meijide, F Nurdiansyah, F. Otten, G. Pe'er, S. Steinbach, S. Tarigan, M.H. Tölle, T. Tscharntke and K. Wiegand. 2017. A review of the ecosystem functions in oil palm plantations, using forests as a reference system. Biological reviews of the Cambridge Philosophical Society 92(3):1539-1569.

Duxbury, A.C., C.S. Yentsch. 1956. Plankton pigment nomographs. Journal of Marine Research (15):92-101.

El -Batanony, N.H. 2017. Synergetic effect of combination of Gracilaria dendroides extract and Azospirillum lipoferaum on growth and yield of sunflower (Helianthusm annuus L.). Egyptian Journal of Experimental Biology (Botany) 13(3): 31-40.

EIIman, G.C. 1959. Tissue sulflydryl groups. Archieve of Biochemistry and Biophysics 82:70-77.

Gutteridge, J.M.C. and C. Wilkins. 1982. Copper dependent hydroxyl radical damage to ascorbic acid formation of thiobarbituric acid reactive products. FEBS Letters 1137:327-40

Habig, W.H, M.J. Pabst and W.B. Jakoby 1974. Glutathione -s-transferases: first enzymic step in mercapturic acid formation. Journal of Biological Chemistry 249:7130139.

Macleod, R.M, W. Farkas, I. Fridovich and P. Handler. 1961. Purification and properties of hepatic sulphite oxidase. Journal of Biological Chemistry 236: 18411846.

Misra, H.P. and I. Fridovich. 1972. The role of superoxide anion in the autooxidation of epinephrine and a sample assay for superoxide dismutase. Journal of Biological Chemistry 247: 3170-3175.

Ng, M.H. and Y.M. Choo. 2010. Determination of antioxidants in oil palm leaves (Elaeis guineensis). American Journal of Applied Science 7(9): 1243-1247.

Nwaogu, L.A. and G.O.C. Onyeze. 2010. Effects of spent engine oil on oxidative stress parameters of Teferia occidentalis leaves. Nigerian Journal of Biochemistry and Molecular Biology 25(2):98-104.

Nwaogu, L.A. and G.O.C. Onyeze. 2014. Effect of chronic exposure to petroleum hydrocarbon pollution on oxidative stress parameters and histology of liver tissues of native fowl (Gallus domesticus). International Journal of Biochemistry Research and Review 4(3):233-242

Nwaogu, L.A., C.E. Onyeze, C.S. Alisi, I.I. Ijeh and G.O.C. Onyeze. 2008. Petroleum hydrocarbon induced changes in tissues of the native fowl (Gallus domesticus) following chronic exposure. Nigerian Journal of Biochemistry and Molecular Biology 23(1): 42-46.

Omarov, R.T., M. Sagi, and S.H. Lips. 1998. Regulation of aldehyde oxidase and nitrate reductase in roots of barley (Hordeum vulgare L.) by nitrogen source and salinity. Journal of Experimental Biology 49:897-902.

Onwurah, I.N.E., V.N. Ogugua, N.B. Onyike, A.E. Ochonogor and O.F. Otitoju. 2007. Crude oil spills in the environment effects and some innovative clean up biotechnologies. International Journal of Environmental Research 1(1): 94 - 104.

Onwusiri, K.C., C.U. Aguoru, and G.F. Akomolafe. 2017. Effect of spent engine oil on germination and growth parameters of fluted pumpkin (Telfaira occidentalis Hook F.) in Markurdi, Benue State, Nigeria. Journal of Research in Forestry and Environment 9(4): 1-8.

Ooi, Z.X., Y.P. Teoh, B. Kunasundari and S.H. Shuit. 2017. Oil palm frond as a sustainable and promising biomass source in Malaysia: A review. American Institute of Chemical Environmental Progress and Sustainable Energy 36: 1864- 1874.

Ortega-Villasante, C.R. Rellán-Álvarez, F.F. del Campo, R.O. Carpena-Ruiz and L.E. Hernández. 2005. Cellular damage induced by cadmium and mercury in Medicago sativa. Journal of Experimental Botany 56:2239-2251.

Osuagwu, A.N., P. Ndubuisi and C.K. Okoro. 2017. Effect of spent engine oil contaminated soil on Arachis hypogeal (L), Zea Mays (L) and Vigna unguiculata (L) Walp. International Journal of Advances in Agricultural Research 5: 76-81 
Rani, P., U.K. Meena and J. Karthikeyan. 2004. Evaluation of antioxidant properties of berries. Indian Journal of Clinical Biochemistry 19 (2): 103-110.

Samina, S. and W.A. Adams. 2002. The fate of diesel hydrocarbons in soils and their effect on the germination of perennial ryegrass. Environmental Toxicology 17: 49-62.

Sgherri, C.L.M., M. Maffei and F. Navari-Izzo. 2000. Antioxidative enzymes in wheat subjected to increasing water deficit and rewatering. Journal of Plant Physiology 157: 273-279.

Sivaraj, R., K.S. Kumar and A. Radhakrishna, 2014. An investigation of growth and yield of Helianthus annuus on diesel contaminated soil and bioremediated diesel contaminated soil. World Journal of Pharmaceutical Research 3(10): 1530-1544.
Stirpe, F. and E. Della Corte. 1969. Regulation of rat liver xanthine oxidase. Conversion in vitro of the enzyme activity from dehydrogenase (type D) to oxidase (type O). Journal of Biological Chemistry 244: 3855-3863.

Tanee, F.B.G. and K. Jude. 2017. Effect of detergent and sawdust addition on hydrocarbon reduction and growth of Abelmoschus esculentus L (Okra) in a petroleumcontaminated soil. Nigerian Journal of Biotechnology 33: 24v-33. DOI: https://dx.doi.org/10.4314/v33i1.4 